NBER WORKING PAPER SERIES

\title{
BANK STRESS TESTING: \\ PUBLIC INTEREST OR REGULATORY CAPTURE?
}

\author{
Thomas Ian Schneider \\ Philip E. Strahan \\ Jun Yang \\ Working Paper 26887 \\ http://www.nber.org/papers/w26887 \\ NATIONAL BUREAU OF ECONOMIC RESEARCH \\ 1050 Massachusetts Avenue \\ Cambridge, MA 02138 \\ March 2020
}

We thank seminar participants at the Columbia University, the Federal Reserve Bank of New York, and Kellogg. The views expressed herein are those of the authors and do not necessarily reflect the views of the National Bureau of Economic Research.

At least one co-author has disclosed a financial relationship of potential relevance for this research. Further information is available online at http://www.nber.org/papers/w26887.ack

NBER working papers are circulated for discussion and comment purposes. They have not been peer-reviewed or been subject to the review by the NBER Board of Directors that accompanies official NBER publications.

(C) 2020 by Thomas Ian Schneider, Philip E. Strahan, and Jun Yang. All rights reserved. Short sections of text, not to exceed two paragraphs, may be quoted without explicit permission provided that full credit, including $\odot$ notice, is given to the source. 
Bank Stress Testing: Public Interest or Regulatory Capture?

Thomas Ian Schneider, Philip E. Strahan, and Jun Yang

NBER Working Paper No. 26887

March 2020

JEL No. G21

\begin{abstract}
$\underline{\text { ABSTRACT }}$
We test whether measures of potential influence on regulators affect stress test outcomes. The large trading banks - those most plausibly 'Too big to Fail' - face the toughest tests. In contrast, we find no evidence that either political or regulatory connections affect the tests. Stress tests have a greater effect on the value of large trading banks' portfolios; the large trading banks respond by making more conservative capital plans; and, despite their more conservative capital plans, the large trading banks still fail their tests more frequently than other banks. These results are consistent with a public-interest view of regulation, not regulatory capture.
\end{abstract}

Thomas Ian Schneider

Old Dominion University

Norfolk, VA 23529

tischnei@odu.edu

Philip E. Strahan

Carroll School of Management

324B Fulton Hall

Boston College

Chestnut Hill, MA 02467

and NBER

philip.strahan@bc.edu
Jun Yang

Notre Dame

South Bend, IN 46556

jyang23@nd.edu 


\section{INTRODUCTION}

Stigler (1971) upended the standard analysis of regulation, arguing that “... as a rule, regulation is acquired by the industry and is designed and operated primarily for its benefit." It is hard to overstate the impact of this idea. Regulatory capture has replaced the public interest theory of regulation, whereby government regulations solve market failures using Pigouvian taxes or by providing public goods, as the dominant paradigm in economics and public choice. ${ }^{1}$ Bank regulation has often been viewed through Stigler's lens, and his argument gained substantial influence in understanding the 2008 Global Financial Crisis (e.g., Johnson and Kwak (2011), Admati, et al. (2013), Acemoglu, et al. (2016), and many others).

In this paper, we assess the implementation of bank stress testing by the U.S. Federal Reserve (the 'Fed'), which is the most important innovation in bank capital regulation to have emerged in the wake of the Financial Crisis. We assess the integrity of the stress test regime by comparing its effects across banks, focusing on differences between banks most likely to be able to influence regulatory decisions and less influential banks. ${ }^{2}$ Contrary to the theory of regulatory capture, we find little evidence that influential banks receive preferential treatment by regulators. This is perhaps surprising because stress testing contains elements often associated with capture theory: the costs and benefits are concentrated among the regulated entities (banks), and the rules and implementation of the regulations are both complex and opaque.

We use three metrics for the potential influence of banks on their regulators. First, we focus on the largest six bank holding companies (Bank of America, Citigroup, JP Morgan Chase, Wells Fargo, Goldman Sachs and Morgan Stanley). These banks - which we will refer to as the

\footnotetext{
${ }^{1}$ Despite this conventional view, empirical support for regulatory capture is mixed (Kalt and Zupan, 1984).

${ }^{2}$ Stress tests are implemented at the level of the Bank Holding Company. To simplify the exposition, and to avoid using clumsy acronyms like BHC, we will refer to these firms as 'banks'.
} 
'large trading banks' - as a group hold about $\$ 11$ trillion in assets in 2018 (more than 50\% of total U.S. banking assets). They are also deeply inter-connected to the global capital markets. We therefore argue that investors plausibly view them as Too Big to Fail (TBTF), meaning that their failure would impose the greatest external costs on the financial system and the broader economy (Strahan, 2012). Given this status, the public interest view of regulation predicts greater regulatory oversight and more capital for them, compared to other banks. Simply put, the largest banks ought to face the toughest tests. Under regulatory capture, in contrast, these largest banks would lobby for, and likely receive, more leniency under the stress tests. We provide unambiguous evidence that the large trading banks face tougher stress tests than other banks.

For our second measure, we build an indicator for banks with executive officers who have held senior positions at bank regulators (e.g., seats of Federal Reserve Bank Boards) during their employment history. Our third measure, one with continuous variation, equals the sum of political contributions made by banks to political candidates and their political action committees (PACs) over the past two congressional election cycles plus their lobbying expenses on regulatory issues. Capture theory would predict that regulatory or political connections help firms gain favoritism, which might lead to more leniency under the tests. We find little evidence of such leniency. Banks connected to regulators are not more affected by the quantitative or qualitative components of stress tests than other banks. Similarly, political donations and lobbying do not correlate to any of the stress test outcomes that we consider.

To understand our specific findings, a few details: The 2008 Financial Crisis initiated dramatic changes in regulation and supervision of financial institutions. In early 2009, at the height of the crisis, the Supervisory Capital Assessment Program (SCAP) represented the first stress testing effort. The SCAP aimed to ensure that the 19 largest banks had sufficient capital coming 
out of the crisis to absorb losses under poor economic conditions and continue supplying credit to the economy, thereby short-circuiting a negative feedback loop between real shocks and financial shocks. Nine banks 'passed' the SCAP outright, and so regulators allowed them to continue operating without needing to raise new equity capital. Of the remaining ten, all but one succeeded in raising sufficient capital in private markets to meet their required capital ratios.

Following the successful SCAP, the Fed decided to implement supervisory stress tests for the large banks (those with assets above $\$ 50$ billion) on a regular basis. The newly renamed Comprehensive Capital Analysis and Review (CCAR), like SCAP, aims to ensure that banks have sufficient capital to absorb losses under an economic and financial downturn to continue lending. To implement CCAR, the Fed specifies three possible economic scenarios (baseline, adverse, and severely adverse). These scenarios represent possible sample paths for risk drivers for the aggregate economy during the 9-quarters following the test. Key risk drivers include housing prices, unemployment rates, economic growth rates, asset prices, interest rates and exchange rates. Under each scenario, the Fed simulates the path of each bank's regulatory capital ratios using its own proprietary model. The minimum value of these ratios under the severely adverse scenario determines the quantitative outcome of the test. All tested banks face the same model and the same economic scenarios. Differences depend on two bank-specific factors: 1) the starting values for positions (which determine each bank's exposure to the risk drivers); and, 2) the bank's commitment for the path of dividends and net share repurchases during the 9-quarter-ahead horizon. In addition, the Fed undertakes a qualitative review of each bank's internal risk management policies and practices. Passage of the CCAR depends on both the qualitative and quantitative aspects of the tests. 
In addition to CCAR, the Dodd-Frank Act requires the Fed to conduct a parallel set of annual stress tests, known as the Dodd-Frank Act Stress Tests (DFAST). These began in 2013. The key difference: under CCAR each bank must propose a capital distribution plan incorporated into the stress test, whereas DFAST uses a standardized capital distribution plan which holds dividends at their current level and sets net repurchases to zero. DFAST also requires banks to run (and disclose) stress tests using the same set of inputs (i.e., the Fed's scenarios and the standard capital distribution plan) but with their own, internally developed model. We use all three sets of quantitative results disclosed publicly: CCAR results; DFAST results from the Fed's proprietary model; and the DFAST results from each bank's own model. ${ }^{3}$ Comparing results across the three approaches allows us to draw inferences about each bank's proposed capital plan (by comparing CCAR results with DFAST, both from the Fed's model) and also to infer how well banks understand the Fed's proprietary model (by comparing the difference between DFAST from the Fed's model with DFAST from the bank's model).

Our first set of tests focuses on the quantitative impact of stress tests on bank portfolios, measured by the decline in capital ratios under DFAST, compared to the capital ratio at the start of the test. As we show, the large trading banks' portfolios decline much more under the stress tests than that of other banks. The difference is large - on the order of two to three percentage points of risk-weighted assets; the difference also persists across all seven stress test cycles (2013 to 2019). The largest banks face greater exposure because their tests include an additional component designed specifically to assess trading risks (the so-called 'Global Market Shock'), which other banks do not face. Our results show that trading banks' capital ratios are hit particularly hard during these scenarios, consistent with the public interest view of regulation. In

\footnotetext{
${ }^{3}$ We do not have access to the details of either the Fed's model or the banks' models, only the publicly disclosed results for the capital ratios built from these models.
} 
contrast, we find no correlation between our other two measures of potential bank influence and the quantitative results of the stress tests.

Second, we consider the likelihood of failing CCAR. We find that the large trading banks are more likely to fail CCAR, even controlling for the quantitative results from their stress tests. There are two possible reasons for this. Either the trading banks report more aggressive capital plans; or, these banks face greater scrutiny on the qualitative dimensions of the tests. We find that the large trading banks submit more conservative capital plans than other banks. This suggests that they are reluctant to commit to an aggressive dividend increase for fear of failing CCAR. The higher rate of failure for the trading banks, despite their conservative capital planning, reflects greater regulatory scrutiny of internal risk-management practices and governance. That is, the biggest banks fail more because of the qualitative dimensions of the test. This effect of stress testing is consistent with good public policy, given the TBTF problem.

In our third set of tests, we explore how banks choose their capital plans, given the constraints imposed by CCAR. Banks face the following tradeoff in making this choice: A more aggressive capital plan brings the benefit of greater freedom to increase dividends in the future, but a more aggressive capital plan also raises the likelihood and cost of failing CCAR. Since banks do not have perfect knowledge of the quantitative results CCAR will produce when they submit their plans (due to the proprietary nature of the Fed's model), their choice can only reflect their best guess of the CCAR results.

We show that trading banks make more conservative capital plans. This result is partly explained by these banks expecting to face a tougher test. In particular, we show that the difference in their capital plans attenuates when we control for the outcomes from the DFAST version of the stress test. We find no significance of the other two measures of potential influence on bank capital 
planning. The capital plans, we show, in fact forecast future dividend distributions, as intended. In other words, commitments made to regulators for the stress test regime matter. As we show, trading banks not only submit more conservative capital plans under CCAR, they also implement more conservative capital distributions. Once we control for their committed capital actions, however, this loses statistical significance.

Fourth, we test whether potentially influential banks have greater understanding of the Fed's models that undergird CCAR by examining differences between banks' and the Fed's minimum projected capital ratios under DFAST. We find no evidence that they do.

We complete the analysis by comparing the evolution of both capital ratios and the two time-varying measures of connectedness, before and after the advent of the stress-testing regime. We show that after the stress tests, regulatory capital ratios for the large trading banks increase relative to other stress-tested banks. Stress testing thus succeeds in recapitalizing the most systemically important banks. We also document that neither regulatory connections nor political/lobbying expenses for the large trading banks shifted relative to the other tested banks. This helps allay the identification concern that exposure to stress tests might drive the connections variables (rather than the reverse, which is the basis of our core analysis).

We contribute to the emerging literature on bank stress testing. Much of this literature focuses on how stress testing has affected large banks' willingness to supply credit. Acharya, Berger and Roman (2017) document that stress-tested banks reduce large corporate loan supply and increase prices particularly for riskier borrowers, while Bassett and Berrospide (2017) do not find any negative impact of stress tests on bank loan growth in general. Cortes, et al. (2019) find that banks exposed to stress tests reallocate small-business credit away from risky markets, but that other lenders fill in the gaps. Chen et al. (2017) show a sharp decline in small business lending 
by the four largest banks that has hurt local economies, and Bord et al. (2018) find that banks with large losses from the Crisis reduced small business lending the most.

There is also considerable debate about the efficacy of stress tests as a means of regulating capital. Frame et al. (2015) illustrate the abject failure of stress testing in preventing the failure of Fannie Mae and Freddie Mac before the financial crisis. Schuermann (2016) questions whether the efficacy of stress testing outside of crisis periods has been adequately thought out by regulators. Hirtle et al. (2009) argue, however, that stress tests have become a key tool in banking supervision. Goldstein and Leitner (2017) theoretically analyze the tradeoffs faced by regulators regarding disclosure of stress test results. They focus on how disclosure of individual bank risks by regulators can affect inter-bank markets and risk sharing. In addition to bank-level results, the Fed has consistently disclosed many other aspects of its stress testing procedures. Disclosure probably makes regulatory capture less likely, particularly given the strong attention of the financial press on the disclosed outcomes of both CCAR and DFAST. Consistent with this conjecture, our results suggest that stress test implementation has been more consistent with a public interest view of banking regulation.

Our paper is closest to studies focusing on distortions or conflicts of interest in regulatory implementation. Studies of the 2008 Financial Crisis report evidence that access to bailouts was higher for politically connected banks (Duchin and Sosyura, 2012; Li, 2013; Berger et al., 2015; Acemoglu et al., 2016), and that recipients of bailout funds took greater risk than other banks (Duchin and Sosurya, 2014). Cornett et al. (2019) provide evidence that stress tested banks spend more on lobbying than other banks. More generally, Agarwal et al. (2014) report that stateregulators are more lenient than federal ones, particularly during periods of local economic stress. Lim et al. (2019) argue that the revolving door between regulators and financial firms leads to 
more risk taking, although Agarwal et al. (2014) and Shive and Forster (2017) report evidence that financial firms employ ex-regulators to acquire their risk-management expertise and other skills. Our paper is the first to consider stress testing through the lens of theories of regulation. In contrast to much of the extant research, our evidence suggests that stress tests have advanced the public interest by subjecting banks plausibly viewed at TBTF to a tougher test, which has in turn led those banks to implement more conservative capital structure policies.

\section{STRESS TESTS: IMPLEMENTATION DETAILS}

Stress testing began in 2009 as a means to ensure that U.S. banks had sufficient capital in the wake of the losses from the 2008 Financial Crisis. The first round of tests (SCAP) succeeded beyond expectation, leading to an inflow of more than $\$ 200$ billion in private capital and a quick end to arguments that U.S. banks should be nationalized (Krugman, 2009). ${ }^{4}$ Over the subsequent years, stress testing evolved into the core of bank capital regulation, particularly for the largest banks (those with assets over $\$ 50$ billion). Our analysis uses data generated from the seven stress test cycles from 2013 through 2019, which constitutes a stable regime in which the process had matured. ${ }^{5}$

To understand our analysis, we first need to describe in more detail how the process works. As noted above, the Fed manages the stress tests, both under its authority as supervisor of banks (CCAR) and also as mandated by the Dodd-Frank Act (DFAST). During each cycle, we use data

\footnotetext{
${ }^{4}$ https://www.federalreserve.gov/newsevents/speech/bernanke20100506a.htm

${ }^{5}$ The basic infrastructure and disclosure did not change over this period, although the sophistication of the models and data requirements have increased over time. Also, in 2019 the smaller banks move to a biannual cycle.
} 
on the effect of the tests on bank capital ratios under three distinct approaches: two mandated by the Dodd Frank Act (DFAST) and one under CCAR. ${ }^{6}$

Under the two DFAST regimes, the 9-quarter ahead path of regulatory capital ratios are generated two ways, once by the Fed using its own proprietary model (which forecasts income, expenses and losses), and in parallel by each bank using its own internal model. The minimum value attained by a given capital ratio over its 9-quarter sample path summarizes the effect of the test, which we often refer to as the 'stressed capital ratio.' 7 We use the term 'DFAST-Fed' to denote outcomes from the Fed's models and 'DFAST-Bank' to denote those based on bank models. We do not observe bank-specific inputs to the models. Both DFAST tests use the same scenarios, determined by the Fed. The specific ratios constructed (and disclosed) have varied somewhat over the seven cycles, so we focus on the three ratios disclosed across all seven cycles: the Tier 1 Risk-Based Capital Ratio, the Total Risk-Based Capital Ratio, and the Tier 1 Leverage Ratio. $^{8}$

The CCAR stress tests share all but one element with DFAST-Fed: both use the same scenarios, the same set of starting values for bank positions, and the same model (that is, the Fed's). The one difference comes from the assumptions regarding capital distributions over the 9-quarterahead planning horizon. DFAST uses a standardized capital plan, extrapolating each bank's current dividend payout over the horizon and zeroing out other forms of capital distributions (e.g., net share repurchases). CCAR, in contrast, requires banks to provide their actual capital

\footnotetext{
${ }^{6} \mathrm{CCAR}$ also requires banks to run stress tests using their own scenario, both with their own model and with the Fed's model. These results are not publicly disclosed, however, but they are used as part of the Fed's assessment of each bank's risk management policies and practices.

${ }^{7}$ The full sample path of the capital ratios are not disclosed, only their starting value, minimum value and end values. In the vast majority of cases, the minimum value equals the end value.

${ }^{8}$ The Tier 1 Common Ratio was discontinued after 2015; Common Equity Tier 1 Capital was implemented in 2014 for select banks and is now reported for all banks; and the Supplementary Leverage Ratio was adopted in 2017 for select banks.
} 
distribution plans over the 9-quarter horizon, including net share repurchases and planned changes (typically increases) in dividends. These proposed capital plans are binding on banks, in that they may not exceed them without prior Fed approval. For our purposes, we build a measure of the increase in each bank's planned capital distributions (as a fraction of current assets) by comparing the difference between the minimum capital ratios from CCAR vs. those of DFAST-Fed. ${ }^{9}$ To a first approximation, the measure equals the difference between the minimum capital ratio under DFAST-Fed minus CCAR, because the capital ratios differ only in the assumed underlying distributions to shareholders - otherwise, the two share the same model, the same scenario, and the same set of positions.

The Fed uses CCAR as its primary tool to assess bank regulatory capital adequacy. According to the Fed, "Comprehensive Capital Analysis and Review (CCAR) is an intensive assessment of the capital adequacy of large, complex U.S. bank holding companies (BHCs), and of the practices these BHCs use to manage their capital. The Federal Reserve expects these BHCs to have sufficient capital to withstand a severely adverse operating environment and be able to continue operations, maintain ready access to funding, meet obligations to creditors and counterparties, and serve as credit intermediaries." Passing CCAR means that a bank may follow its proposed capital plan. Failing CCAR can occur for either quantitative or qualitative reasons. A quantitative failure occurs if one of the regulatory capital ratios over the planning horizon falls below the regulatory minimum. In most such cases, banks may adjust their capital plan downward in order to pass the quantitative hurdle. A qualitative failure occurs if the Fed finds deficiencies in a bank's internal risk management policies or practices. As the Fed say, "The Federal Reserve's

\footnotetext{
${ }^{9}$ Unfortunately, the details of these capital plans - such as the breakdown between dividends and repurchases and the exact timing of changes - are not publicly disclosed. So, we construct a summary measure based on the overall impact of the plans on the capital ratios.
} 
qualitative assessment of the capital plans focused on the robustness of a BHC's internal capital adequacy processes, including each BHC's stress test under its own internally designed stress scenario." In some cases, banks are required to make internal changes but may maintain their stated capital plan ("conditional non-objections"). In these cases, banks commit to making improvements to their risk management practice but receive approval of their planned capital distributions.

Because CCAR creates a direct link from the stress test outcomes to the path for a bank's future dividends, the financial press follows the results closely. For example, when Citigroup failed CCAR in 2014, according to the New York Times: "The Federal Reserve dealt an embarrassing blow to Citigroup on Wednesday, attacking the bank's financial projections for its sprawling operations and denying the bank's plan to increase dividends and repurchase stock." Citi's stock fell about $6 \%$ when the CCAR failure was announced. The Wall Street Journal described the 2015 CCAR as follows: "The Fed said Wednesday it approved revised dividend and stock-buyback plans from the two Wall Street titans after finding their initial requests would have left them both undercapitalized in a hypothetical severe recession. Shares of both firms rose in after-hours trading amid relief that the Fed test wouldn't preclude dividend increases, or in Morgan Stanley's case, a tripling of its share-buyback program."

Over the seven stress test cycles, there were a total of 27 CCAR failures for U.S. banks. Most of the failures involved either downward adjustments to bank capital plans or other required changes. In five cases, however, the Fed objected to the bank's capital plan outright. Below, we model the incidence of CCAR failure with an indicator variable, and we also use a failure score that ranges from 0 (no objection), to 1 (downward adjustment to the capital plan or conditional non-objection) to 2 (objection). 
Figure 1 illustrates the timing of the annual stress test cycle, using dates from 2018 as an example. The tests forecast the path of regulatory capital ratios from 2018 Q1 through 2020 Q1. Model inputs reflect bank positions at the end of 2017. These positions affect the results of both CCAR and DFAST and are used in common as inputs to both the Fed's model and to each bank's model. The Fed announced the three economic scenarios (baseline, adverse and severely adverse) on February 1, 2018. The scenarios announcement comes after banks' positions are determined, thus avoiding the possibility of gaming the test by initiating hedges against positions that might be especially ill affected in a downturn. Banks then have two months - until April 5, 2018 in this example - to provide the Fed with their capital plan for CCAR. With the initial capital plan, the Fed runs its model to simulate each bank's capital path over the 9-quarter-ahead forecast horizon. If a bank's stressed capital ratio falls below the regulatory minimum, the bank may then adjust downward its capital plan such that the stressed ratio does not fall below the minimum. (As noted, we treat a capital-plan adjustment as a CCAR failure.) The Federal Reserve announced publicly the results of both DFAST and CCAR in June of $2018 .{ }^{10}$

\section{DATA AND RESULTS}

\section{III.A Data}

We build our measures of stress test outcomes from the publicly disclosed data for CCAR and DFAST during the seven stress test cycles from 2013 to $2019 .{ }^{11}$ We start in 2013 , the first year of standardized disclosure for both DFAST and CCAR. Each year, the Fed releases first the

\footnotetext{
${ }^{10}$ The first three stress test cycles were disclosed in March, and the latter four in June.

${ }^{11}$ Appendix Table 1 summarizes our variable definitions.
} 
results of DFAST in a document containing the results from the Fed's proprietary model. About one week later, they release a second document with results from CCAR, again containing quantitative results based on the Fed's model, along with a discussion of the qualitative results of the test. ${ }^{12}$ Whether or not a bank 'passes' its stress test depends on the results from CCAR, as these embed each bank's planned capital distribution plan. We include only tested U.S. banks because our measures of connectedness (described below) are not available for the foreign banks. We also construct outcomes from the DFAST results based on each bank's proprietary model; banks must disclose summary measures of these results, as stipulated in the Dodd-Frank Act.

Panel A of Table 1 reports summary statistics for various measures of the stress test outcomes. We capture three capital ratios and three test configurations. The three capital ratios are the Tier 1 Risk-Based Capital Ratio, the Total Risk-Based Capital Ratio, and the Tier 1 Leverage ratio. The first two differ in their numerator but share the same denominator (riskweighted assets); the Tier 1 Leverage Ratio shares the same numerator as the Tier 1 Risk-Based Capital Ratio with a different denominator (total assets). The three test configurations are DFASTFed, DFAST-Bank, and CCAR. Thus, we have nine potential sets of variables, although we focus on a subset of these.

Our first set of outcomes equals the difference between the stressed value for a given capital ratio (under the severely adverse scenario) and its value at the start of the test; these variables measure the exposure of bank portfolios to the test. For the exposure variables, we only consider the results from DFAST, since these embed a standardized capital distribution policy. These exposure variables measure the simulated losses from the test, as summarized by the impact on the capital ratios. The second set of outcomes equal the minimum distance between the stressed value

\footnotetext{
${ }^{12}$ To access these data, go to: https://www.federalreserve.gov/supervisionreg/stress-tests-capital-planning.htm.
} 
of each ratio and its respective regulatory minimum. We pick the capital ratio whose stressed value comes closest to breaching the regulatory minimum, as follows:

Minimum Distance = Min (Stressed Tier 1 Capital-6\%, Stressed Total Risk-based Capital$8 \%$, (Stressed Leverage Ratio-4\%) x (TA/RWA)).

Negative values occur when a bank fails one of the quantitative minimums under the stress test. Notice that we multiply the term Stressed Leverage Ratio $-4 \%$ by the bank's ratio of total assets to risk-weighted assets $(T A / R W A)$. This adjustment puts the leverage-ratio's regulatory deviation on the same scale as the deviation for the other two.

As shown in Panel A, the average bank's capital ratio falls by 2 to 3 percentage points under the severely adverse scenario in the stress test. The two risk-based ratios fall more in absolute terms. For example, the mean of Tier 1 Cap Exposure (using DFAST-Fed) equals 3.53, meaning that the average bank's Tier 1 Capital Ratio falls by 3.53 percent of risk-weighted assets under the severely adverse scenario. Increases in the exposure variables indicate that a bank's portfolio is more sensitive to losses under the test scenario. In contrast, the minimum distance measures capture how close a bank comes to breaching one of the regulatory minimums. The average bank, for example, is 3.89 percentage points above the regulatory minimum based on its own model (Minimum Distance using DFAST-Bank). Using the Fed's (tougher) model, this distance falls to 3.05 percentage points (Minimum Distance using DFAST-Fed). In some cases, including Goldman Sachs (2013) and Zions (2014), this measure goes negative, meaning that a bank breaches one of the three capital ratios.

Although the Fed results are more severe, the stressed capital ratios using bank models are highly correlated with those from the Fed's models. Table 1, Panel B reports these correlations. 
This high correlation suggests that banks can form reasonable expectations for their exposure to the Fed's stress-testing model, which helps them optimize their capital plan under CCAR.

To assess the outcomes of CCAR, we focus on failure. As described in Section II, we build an indicator (Any Failure) and the slightly more informative Failure Score (which varies from 0 to 2). As shown in Panel A, banks fail CCAR about $18 \%$ of the time. CCAR uses each bank's capital plan as a key input. By comparing the stressed capital ratio under CCAR with that under DFAST-Fed, we are able to construct Capital Plan. As shown in Appendix 2, this variable approximates the difference between a bank's planned future distributions to shareholders, minus its current distribution, measured as a fraction of total assets. Thus, Capital Plan measures the expected increase in shareholder payouts over the forecast horizon. The variable Total Distributions equals the bank's realized dividends plus net share repurchases over the first four quarters of the planning horizon for a given stress-test cycle (again, as a fraction of total assets). We build Total Distributions from year-end regulatory reports for bank holding companies (Y9C, and Y-9LP). ${ }^{13}$ Banks distribute a little less than $1 \%$ of assets each year to shareholders, and plan to increase this by 1.19 percentage points of assets by the end of the planned horizon, or about half a percentage point of assets per year $(0.53=1.19 \times 4 / 9)$. This figure seems large, but it reflects not just planned increases in dividends and repurchases, but also the fact that the DFAST capital assumption includes only dividends (and zeros out net repurchases). ${ }^{14}$

Panel C of Table 1 reports summary statistics for our measures of potential bank influence over the stress testing process. We focus on two indicator variables and one continuous variable.

\footnotetext{
${ }^{13}$ https://www.chicagofed.org/applications/bhc/bhc-home.

${ }^{14}$ In our empirical analysis, we control for each bank's fraction of distributions coming from share repurchases to account for this difference.
} 
The first - Trading Bank - equals one for the six largest trading banks: JP Morgan, Bank of America, Citigroup, Wells Fargo, Goldman Sachs, and Morgan Stanley. They together constitute approximately $75 \%$ of the sample in terms of total assets. This set of banks, most plausibly viewed as 'Too Big to Fail,' would face greater scrutiny and more rigorous stress tests than other banks under a public interest view of the process because their failure would impose the greatest external costs on the financial and economic systems.

The second - Regulatory Connection - is constructed using BoardEx data. It equals one if any executive of the bank also holds a senior position (executive, board of director, or senior manager) at any bank regulator during her employment history and zero otherwise. As bank regulators, we consider the Fed, FDIC, OCC, and the Treasury, although all of our connections come from bankers serving on the Board of a Federal Reserve Bank (Appendix 3). The regulatoryconnected banks represent a little bit less than one-third of the stress-tested banks.

The third - Political Donations and Lobbying - measures the total amount of political contributions made by banks to political candidates and political action committees (PACs) plus their lobbying expenses on regulatory matters related to stress testing. These data come from OpenSecrets.org. ${ }^{15}$ We divide total political contributions plus lobbying by lagged assets to account for bank scale. Because contributions are small relative to bank assets, we standardize this variable to mean zero and unit standard deviation for ease of interpretation. Regulatory capture would predict all three measures of influence would lead to weaker application of stress tests.

\footnotetext{
${ }^{15}$ The value of political donations used in 2018 equals the sum of contributions made during the 2016 and 2014 election cycles. Since contribution data is only available at the election-cycle level, including 2018 numbers in our measure for that year would induce look-ahead bias because the 2018 stress tests were conducted in June and the election occurred in November. The lobbying data include filer name, addresses, lobbying income/expenses, general and specific lobbying issues, and lobbyists hired. For our purpose, we include reports that mention any of the following keywords: "stress test", "stress testing", "comprehensive capital analysis and review", "CCAR," and "Dodd," and use the total lobby expenses reported. The quarterly lobby amount is then aggregated to the bank-year level. The Lobbying Reports do not break down the total lobby expenses by general or specific issues.
} 


\section{III.B Results}

\section{III.B.1 Do Stress Test Exposures Reflect Potential Bank Influence?}

To summarize how bank portfolio values decline under the stress tests, we analyze links from our three Exposure variables and the Minimum Distance variable to the three measures of potential bank influence. We report regressions with the following structure:

$$
\begin{gathered}
Y_{i, t}=\beta_{1} \text { Regulatory Connection }_{i, t}+\beta_{2} \text { Trading Bank }_{i} \\
+\beta_{3}(\text { Political Donations and Lobbying })_{i, t} \\
+ \text { Year FEs } \varepsilon_{i, t}
\end{gathered}
$$

where subscript $i$ indicates bank and $t$ indicates year (2013-2019). We report four outcomes in equation (1): Tier 1 Cap Exposure, Total Risk-Based Cap Exposure, Tier 1 Leverage Exposure, and Minimum Distance. We use DFAST-Fed for all four measures, which embeds the standardized capital plan. As such, the results do not reflect heterogeneity in planned capital distributions across banks (unlike CCAR, which we explore below). Since the outcomes depend on a common model (the Fed's), all of the heterogeneity reflects differences in bank portfolio sensitivity to the Fed's chosen scenario.

We report models with year effects, although results are similar without them. ${ }^{16}$ We build standard errors that allow for potential heteroskedasticity and within-bank error correlation by clustering at the bank-level. The sample includes 154 bank-year observations, based on 26 banks

\footnotetext{
${ }^{16}$ We do not control for observable variation in bank portfolios (e.g., loan shares, off-balance sheet positions, etc.) because they are embedded in the stress test outcomes in a much more granular way than is possible from standard datasets. Our aim is to understand how the total impact of stress testing on bank capital varies with measures of influence; controlling for portfolio differences would tend to obscure these differences.
} 
observed across seven years. The panel is unbalanced, as some of the banks, such as Zions, Northern Trust, and CIT Group, do not appear in all of the cycles.

Table 2 reports the results. The large trading banks face much more exposure to stress tests than other banks. All three capital ratios fall more under the stress tests for trading banks than for the other banks; and, the magnitudes of these differences are very large. For example, the Tier 1 Risk-Based Capital ratio falls by almost 3 percentage points more for trading banks than for other banks (Column 2). In contrast, we find no significant effect of connection to regulators or donations to politicians plus lobbying on the exposure measures. The last column of Table 2 also suggests that trading banks wind up closer to regulatory minimums under the stress scenarios than other banks. Again, the magnitude is substantial. Trading banks are almost one percentage point closer to breaching the regulatory minimum due to the stress test, compared to other banks. This matters because breaching one of these lower bounds constitutes a failure of the quantitative portion of CCAR.

Figure 2 shows graphically the stark difference in stress-test exposure experienced by the trading banks, and that this difference is robust across testing cycles. We find that in every year and for each capital ratio, the trading banks experience a larger decline in capital from the test. As noted above, these six banks face an add-on to their test based on a global market shock designed to affect trading positions; this shock increases their simulated losses substantially and leads to larger declines across all three capital ratios and all seven stress test cycles.

Table 3 introduces the value of stress-test exposure constructed from the bank's own internal models to the right-hand side of Equation (1). The large trading banks face an additional source of downside risk in the Fed's scenario design aimed at shocking the value of their trading positions in global capital markets. By controlling for the bank-modeled exposure, which captures 
the effect of the global market shock, we can remove variation due to this difference. ${ }^{17}$ We find, first, that the bank-modeled exposure correlates strongly with that produced by the Fed, as one would expect ( $\mathrm{R}^{2}$ increases substantially). More importantly, the result documents that the Fed's model has greater impact on the large trading banks in ways that go beyond the global market shock. Magnitudes do drop (relative to Table 2), but they remain large. For example, the Fed's model yields an exposure based on the Tier 1 Risk-Based Capital Ratio about 1 percentage point larger for the trading banks than for other banks. As in the results from Table 2, we find no effect of either regulatory connections or political and lobbying expenses.

Taken together, Tables 2 and 3 offer no support for a regulatory capture view of stress testing. If there were, we would observe connected banks and/or the large trading banks facing easier tests, not harder ones (as the trading banks do).

\section{III.B. 2 Who Fails CCAR?}

CCAR adds one additional component to the quantitative stress-testing framework relative to DFAST: an explicit linkage between the test results and each bank's planned future capital distributions to shareholders. As such, passing or failing CCAR potentially constrains a bank's future ability to manage its capital.

Table 4 reports regressions testing whether or not passing CCAR depends on our three measures of potential bank influence. We estimate the outcome using either a simple indicator variable (Failure $=1$ if a bank fails CCAR), and using an outcome which distinguishes between failures that are rectified either by a reduction in the capital plan or some other mitigation verses

\footnotetext{
17 The estimation of exposure to the global market shock embedded in DFAST-Fed comes from the bank's own internal assessments of these exposures. According to the disclosure document for DFAST in 2013 (page 12), "The FR Y-14 schedules collect BHC estimated sensitivities of these positions to the set of risk factors specified by the Federal Reserve, including changes in a wide range of U.S. and global market rates and asset prices as well as volatilities of those rates and prices." Thus, exposure to the shock is presumably identical under both DFAST-Fed and DFASTBank.
} 
an outright rejection by the Fed. This second measure (Failure Score) takes the value of 0 for unconditional passes, 1 for conditional passes or adjustments to the capital plan, and 2 for outright objections. We estimate models that first condition on the DFAST-Bank results and then condition on the DFAST-Fed results (neither of which captures banks' planned capital actions). We build two variables: the Minimum Distance measure and an indicator equal to one if the Minimum Distance variable falls below zero (i.e., this variable equals one if one of the stressed capital ratios breaches its regulatory minimum). Note that this latter variable (Below Any Barrier) never takes the value of one using the bank's model, so we cannot estimate its coefficient using the bankmodeled results.

As expected, failing CCAR is closely linked to a bank's quantitative results from the Fed's model, and this result is driven by the simple indicator equal to one for banks who breach one of the regulatory minimums (Columns 2 and 4 of Table 4). In contrast, we find no correlation between the outcomes from bank models and CCAR failure. Both measures of bank connections to regulators and political donations plus lobbying expenses enter the models with small coefficients. The Trading Bank indicator enters consistently with a positive and significant coefficient; large trading banks are more likely to fail CCAR. The magnitude is substantial, with trading banks' failure rates 17 to 22 percentage points higher (using the indicator variable model). The result for trading banks is robust across all four models. ${ }^{18}$ Because our model controls for the quantitative results using the Fed's model (Columns $2 \& 4$ ), the observed result captures either differences in banks' planned capital actions (higher planned payments raise the odds of failing), or differences in the toughness of the qualitative portion of the test.

III.B.3 Capital Distributions: Planned Actions v. Actual Payments

\footnotetext{
${ }^{18}$ Appendix Table 4 reports the incidence of CCAR failure for each stress test cycle.
} 


\section{Planned Capital Actions}

Table 5 reports regressions of the Capital Plan on our measures of potential bank influence and Minimum Distance (from DFAST-Bank). The latter variable captures each bank's exposure to the test based on the standard capital plan. We condition on results from DFAST-Bank because these results are known to banks when they provide the capital plan to the Fed. The regressions test whether potentially influential banks - those connected to regulators, those connected to the political system, or those most likely to be TBTF - are more or less aggressive in their capital planning. By controlling for the quantitative outcome of the test, we can determine whether capital planning is more aggressive at banks that have a larger capital cushion relative to the regulatory minimums (after the test). Banks know the Minimum Distance from their own model before they submit the capital plans for CCAR (recall the timeline in Figure 1). However, they do not know the Minimum Distance from DFAST-Fed, which is what matters for CCAR. Banks must use their internally modeled capital ratios to generate an expectation for their exposure to the Fed's model. Hence, we expect banks' capital plans to be more aggressive if their Minimum Distance is higher. The regressions also include the percentage of distributions from share repurchases because the standardized capital plan under DFAST does not capture expected future repurchases. Thus, banks that typically use repurchases will, all else equal, tend to have a higher value of Capital Plan. ${ }^{19}$

In the simple models (column 1), we find strong evidence that trading banks make less aggressive capital plans than other banks. The other two measures of potential influence, however, exhibit no significance. Controlling for the quantitative results from the test - that is, adding Minimum Distance - removes the significance of Trading Bank. Thus, the large trading banks

\footnotetext{
${ }^{19}$ Recall that the Capital Plan is close to the difference between the minimum value of the capital ratio under DFAST - the minimum under CCAR, and some of this gap reflects the fact that CCAR captures planned share repurchases while DFAST does not.
} 
make less aggressive plans for future dividend and share repurchases because they know that they face more exposure to the quantitative components of the stress tests. (Recall that we show this in Tables 2 and 3.) Despite their more conservative capital planning, however, the trading banks still fail CCAR at greater rates than other banks. These results together imply that the trading banks face greater scrutiny from the qualitative component of CCAR.

To summarize: stress tests have greater effect on the value of the portfolios of large trading banks; large trading banks make more conservative capital plans for the CCAR; and, large banks fail CCAR at higher rates than other banks.

\section{$\underline{\text { Actual Capital Actions }}$}

Do planned capital actions made under CCAR work as intended? That is, do they really constrain bank capital distributions? To answer these questions, we link capital plans to actual dividend and share repurchase behavior. We report regressions of actual dividends and share repurchases in the four quarters following a given test (say, 2017Q3 to 2018Q2) on capital plans submitted during that testing cycle (say, 2017). The timing takes account of the fact that the 2017 stress test cycle, for example, forecasts capital ratios from 2017Q1 to 2019Q1. We restrict our analysis to four quarters of distributions rather than nine since payout policy is most directly governed by the results of the most recent stress test.

Table 6 reports these regressions, with a similar pattern to that observed from the capital plan. That is, unconditionally the large trading banks pay less than other banks, by about 0.4 percent of total assets (Column 1). Once again, there is no significant effect of the other two measures of potential influence on bank payouts. As shown in the even-numbered columns, Capital Plan strongly predicts actual payments. Once we include this variable, the effect of Trading Bank on capital distributions falls substantially (because the trading banks commit to less 
aggressive capital plans than other banks). Hence, capital planning does in fact constrain actual distributions, as intended.

\section{III.B.4 Stress Test Uncertainty}

Do potentially influential banks have a better understanding of the Fed's proprietary models? Some have argued that banks have strong incentives to try to mimic the Fed's models, and certainly a bank's ability to do so would raise concerns about possible regulatory arbitrage strategies (Schuermann, 2013).

To test whether convergence between bank-modeled v. Fed-modeled results varies with influence, we regress the absolute and squared difference between the three stressed capital ratios using DFAST-Fed outcomes v. DFAST-Bank outcomes, again as functions of our influence metrics (Table 7). These results do not support the idea that trading banks, banks connected to regulators, or banks that donate more to the political system have any better ability to mimic the Fed's specific modeling of the stress tests. This non-result suggests a level playing field across the stress-tested banks, consistent with the public interest view of regulation. That said, it is clear that stressed outcomes from bank models are strongly correlated with those from the Fed's models (recall Table 3).

\section{III.B.5 Difference-in Differences Analysis: Stress Tests and the Evolution of Bank Capital}

We have argued that the large trading banks face the toughest stress tests, which lead them to adopt more conservative capital plans than other tested banks. If true, then their capital ratios ought to increase after the advent of stress tests, and their ratios ought to increase more than that of other stress-tested banks.

The four panels of Figure 3 show exactly this pattern. We plot the average levels of the three capital ratios for the large trading banks vs. the other stress-tested banks, as well as their 
capital distributions. ${ }^{20}$ For each ratio, the trading banks have lower capital before the Financial Crisis, but this difference exhibits no trend (i.e., pre-trends are parallel). After the crisis - that is, after the advent of stress testing - capital increases for all of the banks but the differences decline. In fact, by 2012 the large trading banks have higher levels of both measures of risk-based capital. The differences in capital continue to trend upward until 2018 because the effects of the more conservative capital distributions from the trading banks cumulate over time. As shown in the fourth panel, the large trading banks paid more out to shareholders before the advent of stress testing than the other tested banks but less after.

To quantify the average differential effect of stress testing on the three capital ratios, Table 8 reports estimates from difference-in-differences regressions of the following type:

$$
Y_{i, t}=\beta \text { Trading Bank }_{i} \times \text { Post }_{\mathrm{t}}+\text { Year FEs }+\varepsilon_{i, t}
$$

where $Y_{i, t}$ represents one of the three capital ratios or the payout ratio; TradingBank $k_{i}$ equals 1 for the six large trading banks; and, Post $t=1$ from 2013 on. We drop the crisis years (2007-2009) because the capital ratios move substantially due to both crisis interventions (e.g., government capital injections from the Troubled Asset Relief Program) as well as from mergers (e.g., Wells Fargo acquires Wachovia; JP Morgan acquires Washington Mutual, etc.). The Post indicator turns to one after the stress test regime comes fully into effect. ${ }^{21}$ The regressions show that the relative increase in capital for the trading banks is large, both statistically and economically. The increase ranges from more than two percentage points for the risk-based capital ratios to one percentage

\footnotetext{
${ }^{20}$ The surprising increase in the capital ratios in 2008 for the largest banks occurs because we plot fourth quarter values, and these ratios increased sharply at the end of 2008 due to TARP capital injections.

${ }^{21}$ Setting Post to one in 2010, 2011 or 2012 generates somewhat smaller estimates, consistent with Figure 3.
} 
point for the leverage ratio. Capital distributions are also lower for the large trading banks, but this difference is not statistically significant. ${ }^{22}$

\section{III.B.6 Difference in Differences Analysis: Stress Tests and the Evolution of Regulatory}

\section{Connections and Political/Lobbying Expenses}

Our tests relating both regulatory connections and political plus lobbying expenses have assumed one-way causation. This is potentially problematic, as one might argue that banks with greater exposure to stress tests choose to increase their influence, either by building a closer relationship with their regulator or by trying to influence the political system with money. Such behavior would tend to bias the effects of regulatory capture toward zero. For example, if bankers which are (unobservably) more affected by stress tests seek to hold board seats at their Federal Reserve Bank, this would impart and upward bias on the coefficients in regressions such as those in Tables 2 and 3.

We attempt to rule out this identification problem by testing whether regulatory connections or political/lobbying expenses react positively to an observable measure of stress-test exposure. This comes down to estimating difference-in-differences regressions like Equation (2) using the potentially endogenous regulatory connection indicator and political \& lobbying expenses as outcomes. Trading Bank, as we have seen, is a strong observable bank characteristic which increases stress-test exposure.

As reported in Table 9, we see no evidence for an endogenous response to stress-test exposure. Trading banks - banks most exposed to stress testing - are not more likely to connect

\footnotetext{
22 The dependent variable equal the year-end value of the regulatory capital ratios, and the sample includes only the stress-tested banks. We include the pre-crisis years back to 2001. We have also estimated these regressions without Goldman Sachs and Morgan Stanley because these two firms only became banks in the wake of the Lehman catastrophe, so we have no 'pre-period' for them. These results are similar to those in Table 8.
} 
to their regulator, nor are they increasing their expenses on politics or lobbying, relative to lessexposed banks. If anything, we see the reverse, as the coefficient on Trading Bank $x$ Post-2013 enters negatively.

\section{Conclusions}

We have tested whether three measures of potential influence of banks over their regulators affect stress test outcomes. The large trading banks - those most likely to be 'Too Big to Fail' face the toughest tests. Stress tests have a greater effect on the value of their portfolios; the large trading banks respond to their greater exposure by committing to more conservative capital plans; and, despite their more conservative capital planning - which is manifest not only in what banks promise to pay but also in what they actually pay - the large trading banks still fail CCAR at higher rates than other banks. We think it is hard to understand these results through the lens of regulatory capture. On the contrary, tougher tests and more conservative capital planning for plausibly Toobig-to-Fail banks aligns with the public's best interests. We find little evidence that measures of either political or regulatory connections affect the tests.

Stigler's economic theory of regulation supposes that regulators behave as self-interested, maximizing agents. Since regulated entities (e.g., banks) typically have powerful incentives to reward regulators while the public does not, Stigler argued that outcomes would typically be captured by industry. Our analysis of the new capital regime which emerged from the wreckage of the Global Financial Crisis finds no evidence of capture. In building the new regime, however, regulators faced extreme pressure to strengthen the capital requirement, having been blamed for the Crisis by many observers. Thus, tough capital requirements on the largest banks may well reflect regulators' self-interested behavior after all. As we move further from the crisis, however, 
pressure for regulatory oversight has fallen. Banks and their advocates have complained about various aspects of stress testing, such as its opacity, and this advocacy has had an impact very recently. For example, in 2019 the Fed increased its disclosure of both scenario design and its own proprietary models, which increases the possibility of regulatory arbitrage in the future. In addition, after 2019 the Fed will move the qualitative assessments into its normal supervisory practice, which likely implies less future disclosure of the results from the stress tests. ${ }^{23}$ These changes may suggest more influence of the industry over stress testing going forward.

${ }^{23}$ See Quarles (2019), at https://www.federalreserve.gov/newsevents/speech/quarles20190709a.htm 


\section{REFERENCES}

Acharya, V., Berger, A., Roman, R., 2018. Lending implications of U.S. bank stress tests: Costs or benefits? Journal of Financial Intermediation 34, 58-90.

Admati, A. and M. Hellwig. 2013. The Bankers' New Clothes: What's wrong with banking and what to do about it. Princeton University Press.

Acemoglu, D, Simon Johnson, Amir Kermani, James Kwak, and Todd Mitton. 2016. The value of connections in turbulent times: Evidence from the United States. Journal of Financial Economics 121, 368-91.

Bassett, W., Berrospide, J., 2018. The impact of post stress tests Finance and EconomicsDiscussion on bank lending. Board of Governors of the Federal Reserve System, Series 2018-087.

Bord, V., Ivashina, V., Taliaferro, R., 2018. Large banks and small firm lending. NBER Working Paper No. 25184.

Cameron, A.C., J.B. Gelbach, and D.L. Miller. 2008. Bootstrap based improvements for inference with clustered errors. The Review of Economics and Statistics, 90(3), 414-417.

Candelon, B. and Sy, A. 2015. How did markets react to stress tests? IMF Working Paper No. 15/75.

Chen, B., Hanson S., and Stein J., 2017. The decline of big-bank lending to small business: Dynamic impacts on local credit and labor markets. NBER Working Paper No. 23843.

Connolly, M., 2018. The real effects of stress testing. Boston College Unpublished working paper.

Cornett, M. M., K. Minnick, P Schorno, and H. Tehranian, 2019. An examination of bank behavior around Federal Reserve stress tests. Journal of Financial Intermediation, forthcoming.

Cortés, K.R., Y. Damyanyk, L. Li, E. Loutskina and P.E. Strahan. 2019. Stress testing and small business lending. Journal of Financial Economics.

Covas, F., 2017. Capital requirements in supervisory stress tests and their adverse impact on small business lending. The Clearing House Staff Working Paper 2017-2. 
Duchin R. and D. Sosyura. 2012. The Politics of Government Investment. Journal of Financial Economics 106, 24-48.

Duchin R. and D. Sosyura. 2014. Safer Ratios, Riskier Portfolios: Banks' Response to Government Aid. Journal of Financial Economics 113, 1-28.

Feldman, R. and Stern, G., 2004. Too Big to Fail: The Hazards of Bank Bailouts. Brookings Institution Press, Washington, DC.

Fernandes, M., Igan D., Pinheiro, M., 2015. March madness in Wall Street: (What) does the market learn from stress tests? IMF Working Paper 15/271.

Flannery, M., Hirtle B., and Kovner A., 2017. Evaluating the information in the Federal Reserve stress tests. Journal of Financial Intermediation 29, 1-18.

Frame, S., Gerardi, K., and Willen P., 2015. The failure of supervisory stress testing: Fannie Mae, Freddie Mac, and OFHEO. Federal Reserve Bank of Atlanta Working Paper 2015-3.

Goldstein, I., Leitner, Y., 2018. Stress tests and information disclosure. Journal of Economic Theory $177,34-69$.

Hirtle, B., Schuermann T., Stiroh K., 2009.Macroprudential supervision of financial institutions: lessons from the SCAP. Federal Reserve Bank of New York Staff Report 409.

Johnson, S. and J. Kwak. 2011. Thirteen Bankers: The Wall Street Takeover and the Next Financial Meltdown.

Kalt, Joseph P., and Mark A. Zupan, 1984. "Capture and Ideology in the Economic Theory of Politics," American Economic Review, 74(3), 279-300.

Krugman, P. 2009. Banking on the Brink. New York Times, Feb. 22, 2009 Op-Ed.

Li, L. 2013. TARP funds distribution and bank loan supply. Journal of Banking and Finance.

Lim, I., J. Hagendorff, S. Armitage. 2018. Is the fox guarding the hen house? Banker in the Federal Reserve, bank leverage and risk shifting. Journal of Corporate Finance. 
Agarwal, S., D. Lucca, A. Seru and F. 2014. Inconsistent Regulators: Evidence from Banking. The Quarterly Journal of Economics, 129 (2), 889-938.

Schuermann, T., 2016. Stress testing in wartime and in peacetime. Oliver Wyman and Wharton Financial Institutions Center.

Shive, S. and M. Forster. 2017. The revolving door for financial regulators. Review of Finance 21 (4), 1445-1484.

Stigler, G. 1971. The economic theory of regulation. Bell Journal of Economics, 2(1), 3-21.

Strahan, P., 2013. Too big to fail: Causes, consequences and policy implications. Annual Review of Financial Economics 5(1), 43-61. 


\section{Appendix 1: Data Definitions}

\begin{tabular}{ll}
\hline Variable Name & Variable Description \\
\hline $\begin{array}{l}\text { Outcome Sources } \\
\text { DFAST Outcomes - Fed }\end{array}$ & $\begin{array}{l}\text { Stressed capital ratios from the Dodd Frank Act Stress Test as calculated and } \\
\text { disclosed by the Fed. }\end{array}$ \\
DFAST Outcomes - Bank & $\begin{array}{l}\text { Stressed capital ratios from the Dodd Frank Act Stress Test as calculated and } \\
\text { disclosed by Banks. } \\
\text { Ctressed capital ratios from the Comprehensive Capital Analysis and Review as } \\
\text { calculated and disclosed by the Fed. }\end{array}$ \\
\hline Capital Ratios & Tier 1 Risk-Based Capital Ratio: Tier 1 Capital divided by Risk Weighted Assets. \\
T1 Capital & $\begin{array}{l}\text { Total Risk-Based Capital Ratio: Total Risk-Based Capital divided by Risk } \\
\text { Weighted Assets. }\end{array}$ \\
TRBC & Tier 1 Leverage Ratio: Tier 1 Capital divided by Total Assets. \\
T1 Leverage & $\begin{array}{l}\text { The minimum projected value of a capital ratio during the 9-quarter-ahead horizon } \\
\text { under the severely adverse stress test scenario. } \\
\text { Ratio Measurements } \\
\text { Stressed Ratio }\end{array}$ \\
$\begin{array}{l}\text { Thitial of Ratio } \\
\text { Exposure of Ratio }\end{array}$ & $\begin{array}{l}\text { The difference between a capital ratio's initial value and minimum value. } \\
\text { The minimum distance between a bank's minimum capital ratios and their } \\
\text { respective threshold values as mandated by the Fed. }\end{array}$ \\
\hline
\end{tabular}

\section{CCAR Outcomes}

Any Failure

A binary measure equal to one if a bank receives an adjustment, conditional nonobjection, or objection, as detailed in Appendix 3.

Failure Score

A categorical measure equal to one if a bank receives an adjustment or conditional non-objection, equal to two for objections, and zero otherwise, as detailed in Appendix 3.

\section{Capital Plan Measures}

Capital Plan

An imputed measure of the bank's capital plan, as detail in Appendix 2.

Total Distributions

Dividends plus net share repurchases, divided by lagged total assets, measured over the four quarters following a stress test.

Percent Repurchase

Net share repurchases divided by Total Distributions.

\section{Influence Measures}

Trading Bank

A binary measure that equals one for the six largest trading banks: JP Morgan, Bank of America, Citigroup, Wells Fargo, Goldman Sachs, and Morgan Stanley.

Regulatory Connection

A binary measure that equals one if any executive of the bank also holds a senior position (executive, board of director, or senior manager) at any bank regulator (Fed, FDIC, OCC, or Treasury) during her employment history, as detailed in Appendix 4.

Political Donations and Lobbying The total amount of political contributions made by banks to political candidates and political action committees over the past two congressional election cycles, plus their lobbying expenses on regulatory matters related to stress testing, divided by total assets and standardized to mean zero and unit standard deviation. 


\section{Appendix 2: Measuring a Bank's Capital Plan}

Assume we forecast capital at the end of the period under the stressed scenario, so we have a two period world: today (0) and the end of the stress test (1).

Let:

$\mathrm{K}_{0}=$ capital at the start of the test;

$\mathrm{A}_{0}=$ 'assets' at the beginning of the test (by which we mean the denominator of the relevant risk-weighted regulatory capital ratio);

$\mathrm{D}=$ net capital distributions;

ATNI $=$ after-tax net income under the stress scenario.

Note: We assume that the "change in adjustments and deductions from regulatory capital + other additions to regulatory capital" term is either zero or common across the DFAST and CCAR versions of the test. We also assume zero growth in liabilities, which implies that the change in capital is equal to the change in assets. We believe this is reasonable since growth will likely be low during a stress event.

We use superscripts to distinguish variables that differ between the DFAST and CCAR. Critically, ATNI is the same under both CCAR and DFAST. This is the random component of the stress test that depends on the bank's starting positions, the Fed's chosen scenario, and the underlying model mapping positions and scenarios into ATNI.

The following derivation assumes a two period world in which the flows are realized at the end of the period. $\mathrm{D}^{\mathrm{DFAST}}$ and $\mathrm{D}^{\mathrm{CCAR}}$ are the capital distributions under the two approaches. The goal is to compute their difference.

Let $\kappa^{\mathrm{DFAST}}$ and $\kappa^{\mathrm{CCAR}}$ be the minimum capital ratio from the tests, which are time 1 variables (that is, end of period). For CCAR, we use the minimum capital ratio for each bank's initial capital plan (as opposed to the more conservative one for bank's who must adjust their capital plan in order to avoid having the stressed capital ratio violate one of the regulatory minimums).

$\mathrm{K}_{0} / \mathrm{A}_{0}=$ the starting value for the capital ratio $=\kappa_{0}$

We can observe $\kappa_{1}{ }^{\mathrm{DFAST}}$ and $\kappa_{1}{ }^{\mathrm{CCAR}}$, but we cannot separately observe the numerator and denominator of these two stress-test outcomes. Note that $\kappa_{0}$ is also disclosed and hence observable.

Starting with DFAST:

$$
\kappa^{\mathrm{DFAST}}=\left(\mathrm{K}_{0}+\mathrm{ATNI}-\mathrm{D}^{\mathrm{DFAST}}\right) /\left(\mathrm{A}_{0}+\mathrm{ATNI}-\mathrm{D}^{\mathrm{DFAST}}\right)
$$

We have a similar equation for CCAR, as follows:

$$
\kappa^{\mathrm{CCAR}}=\left(\mathrm{K}_{0}+\mathrm{ATNI}-\mathrm{D}^{\mathrm{CCAR}}\right) /\left(\mathrm{A}_{0}+\mathrm{ATNI}-\mathrm{D}^{\mathrm{CCAR}}\right)
$$


ATNI is the earnings (or losses) that are modeled by the stress test. It is common to both DFAST and CCAR, hence there is no need to have a superscript. Again, the problem is that we don't observe this number, so we need to work to get rid of it.

To do so, first re-arrange equation 1a, as follows:

$$
\begin{aligned}
\mathrm{D}^{\mathrm{DFAST}} & =\left\{\left(\mathrm{K}_{0}-\mathrm{ATNI}\right)-\kappa^{\mathrm{DFAST}}\left(\mathrm{A}_{0}+\mathrm{ATNI}\right)\right\} /\left(1-\kappa^{\mathrm{DFAST}}\right) \\
& =\mathrm{ATNI}+\left(\mathrm{K}_{0}-\mathrm{A}_{0} \kappa^{\mathrm{CDFAST}}\right) /\left(1-\kappa^{\mathrm{DFAST}}\right)
\end{aligned}
$$

Re-arrange 1b, as follows:

$$
\begin{aligned}
\mathrm{D}^{\mathrm{CCAR}} & =\left\{\left(\mathrm{K}_{0}-\mathrm{ATNI}\right)-\kappa^{\mathrm{CCAR}}\left(\mathrm{A}_{0}+\mathrm{ATNI}\right)\right\} /\left(1-\kappa^{\mathrm{CCAR}}\right) \\
& =\mathrm{ATNI}+\left(\mathrm{K}_{0}-\mathrm{A}_{0} \kappa^{\mathrm{CCAR}}\right) /\left(1-\kappa^{\mathrm{CCAR}}\right)
\end{aligned}
$$

Now, subtract (2a) from (2b), and divide both sides by $\mathrm{A}_{0}$ :

$$
\begin{aligned}
& \left(\mathrm{D}^{\mathrm{CCAR}}-\mathrm{D}^{\mathrm{DFAST}}\right) / \mathrm{A}_{0}= \\
& \left(\mathrm{K}_{0} / \mathrm{A}_{0}-\kappa^{\mathrm{CCAR}}\right) /\left(1-\kappa^{\mathrm{CCAR}}\right)-\left(\mathrm{K}_{0} / \mathrm{A}_{0}-\kappa^{\mathrm{DFAST}}\right) /\left(1-\kappa^{\mathrm{DFAST}}\right)
\end{aligned}
$$

Remembering that $\mathrm{K}_{0} / \mathrm{A}_{0}=\kappa_{0}$ (which we observe) and re-arranging, we obtain:

$$
\begin{aligned}
& \left(\mathrm{D}^{\mathrm{CCAR}}-\mathrm{D}^{\mathrm{DFAST}}\right) / \mathrm{A}_{0}= \\
& \left(\kappa^{\mathrm{DFAST}}-\kappa_{0}\right) /\left(1-\kappa^{\mathrm{DFAST}}\right)-\left(\kappa^{\mathrm{CCAR}}-\kappa_{0}\right) /\left(1-\kappa^{\mathrm{CCAR}}\right)
\end{aligned}
$$

These calculations can be made with any of the disclosed capital ratios. We find similar results, regardless of which ratio we use. In the paper, we report results using the Tier 1 Leverage Ratio. 


\section{Appendix 3: Regulatory Connections}

\begin{tabular}{|c|c|c|c|c|}
\hline Executive Name & Bank & $\begin{array}{c}\text { Term at } \\
\text { Bank }\end{array}$ & Connected Regulator & $\begin{array}{c}\text { Term at } \\
\text { Regulator }\end{array}$ \\
\hline Ralph W. Babb, Jr. & Comerica Inc. & 2001-2019 & Federal Reserve Bank of Chicago & 2004-2008 \\
\hline Jamie Dimon & JPMorgan & 2004-2019 & Federal Reserve Bank of New York & $2007-2012$ \\
\hline James P. Gorman & Morgan Stanley & 2010-2019 & Federal Reserve Bank of New York & 2016-2019 \\
\hline O. B. Grayson Hall, Jr. & Regions Financial Corp. & $2008-2018$ & Federal Reserve Bank of Atlanta & 2017-2019 \\
\hline Joseph L. Hooley, III & State Street Corp. & $2006-2018$ & Federal Reserve Bank of Boston & 2014-2019 \\
\hline Kevin T. Kabat & Fifth Third Bancorp & $2007-2016$ & Federal Reserve Bank of Cleveland & 2014-2016 \\
\hline Beth E. Mooney & Keycorp & 2010-2019 & Federal Reserve Bank of Cleveland & 2016-2018 \\
\hline David W. Nelms & Discover Financial Service & $2007-2018$ & Federal Reserve Bank of Chicago & 2015-2019 \\
\hline William H. Rogers, Jr. & SunTrust Banks Inc. & 2011-2019 & Federal Reserve Bank of Atlanta & 2012-2016 \\
\hline James E. Rohr & PNC Financial Services & $1992-2014$ & Federal Reserve Bank of Cleveland & $2008-2011$ \\
\hline Stephen D. Steinour & Huntington Bancshares Inc. & 2009-2019 & Federal Reserve Bank of Cleveland & 2017-2019 \\
\hline John G. Stumpf & Wells Fargo & 2006-2016 & Federal Reserve Bank of San Francisco & 2015-2016 \\
\hline Frederick H. Waddell & Northern Trust Corp. & 2006-2019 & Federal Reserve Bank of Chicago & $2009-2015$ \\
\hline
\end{tabular}




\section{Appendix 4: CCAR Failure Type by Bank and Year}

\begin{tabular}{|c|c|c|c|c|}
\hline \multirow[b]{2}{*}{ Year } & \multirow[b]{2}{*}{ Banks } & \multicolumn{2}{|c|}{ Failure Score $=1$} & \multirow{2}{*}{$\begin{array}{c}\text { Failure Score = } \\
\text { Objection }\end{array}$} \\
\hline & & Adjustment & $\begin{array}{l}\text { Conditional } \\
\text { Non-objection }\end{array}$ & \\
\hline \multirow{5}{*}{2013} & Ally Financial Inc. & $x$ & & $x$ \\
\hline & American Express Company & $\mathrm{x}$ & & \\
\hline & BB\&T Corporation & & & $\mathrm{x}$ \\
\hline & Goldman Sachs Group, Inc. & & $\mathrm{x}$ & \\
\hline & JPMorgan Chase \& Co. & & $\mathrm{x}$ & \\
\hline \multirow{5}{*}{2014} & Bank of America Corporation & $\mathrm{x}$ & & \\
\hline & Citigroup Inc. & & & $\mathrm{x}$ \\
\hline & Citizens Financial Group/RBS & & & $\mathrm{x}$ \\
\hline & Goldman Sachs Group, Inc. & $\mathrm{x}$ & & \\
\hline & Zions Bancorporation & & & $\mathrm{x}$ \\
\hline \multirow{4}{*}{2015} & Bank of America Corporation & & $\mathrm{x}$ & \\
\hline & Goldman Sachs Group, Inc. & $x$ & & \\
\hline & JPMorgan Chase \& Co. & $\mathrm{x}$ & & \\
\hline & Morgan Stanley & $\mathrm{x}$ & & \\
\hline \multirow{2}{*}{2016} & M\&T Bank Corporation & $\mathrm{x}$ & & \\
\hline & Morgan Stanley & & $\mathrm{x}$ & \\
\hline \multirow{2}{*}{2017} & American Express Company & $\mathrm{x}$ & & \\
\hline & Capital One Financial Corporation & $\mathrm{x}$ & $\mathrm{x}$ & \\
\hline \multirow{7}{*}{2018} & American Express Company & $\mathrm{x}$ & & \\
\hline & Goldman Sachs Group, Inc. & $\mathrm{x}$ & $\mathrm{x}$ & \\
\hline & JPMorgan Chase \& Co. & $\mathrm{x}$ & & \\
\hline & KeyCorp & $\mathrm{x}$ & & \\
\hline & M\&T Bank Corporation & $\mathrm{x}$ & & \\
\hline & Morgan Stanley & $\mathrm{x}$ & $\mathrm{x}$ & \\
\hline & State Street Corporation & & $\mathrm{x}$ & \\
\hline \multirow{2}{*}{2019} & Capital One Financial Corporation & $\mathrm{x}$ & & \\
\hline & JPMorgan Chase \& Co. & $x$ & & \\
\hline
\end{tabular}


Figure 1: Stress Test Timeline

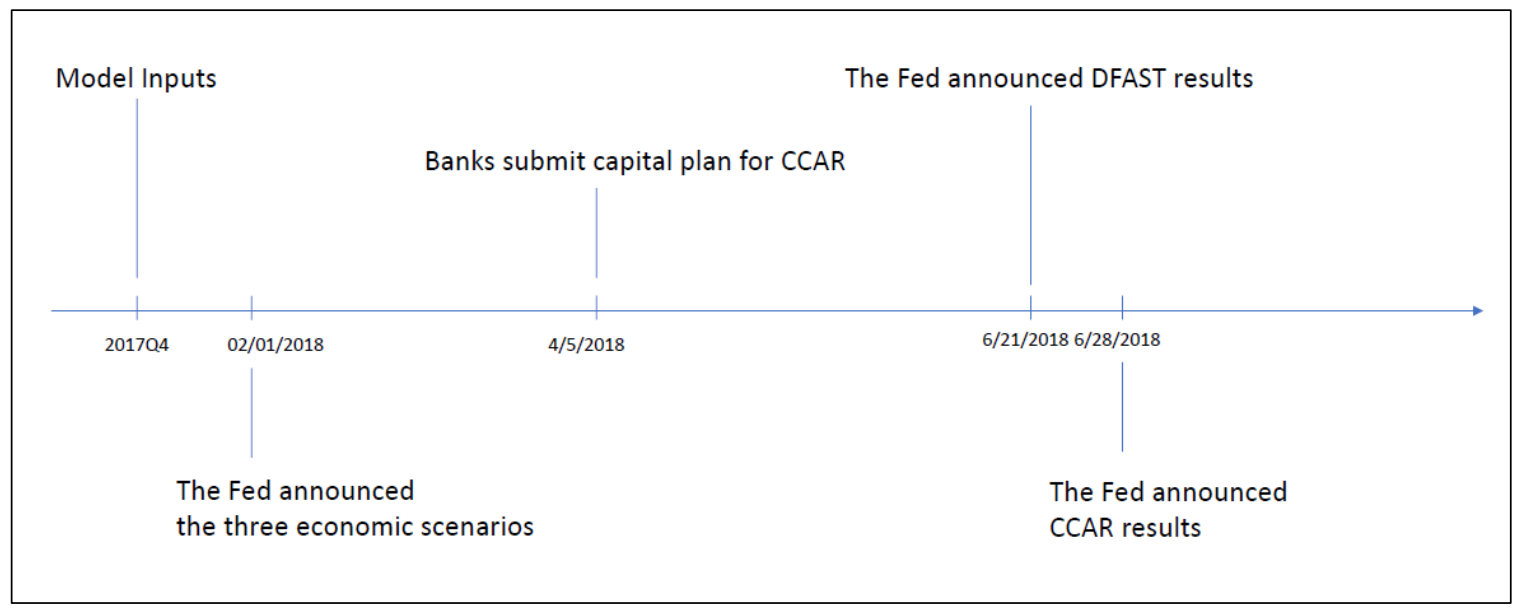


Figure 2: Stress Test Exposure - Trading vs Non-Trading Banks
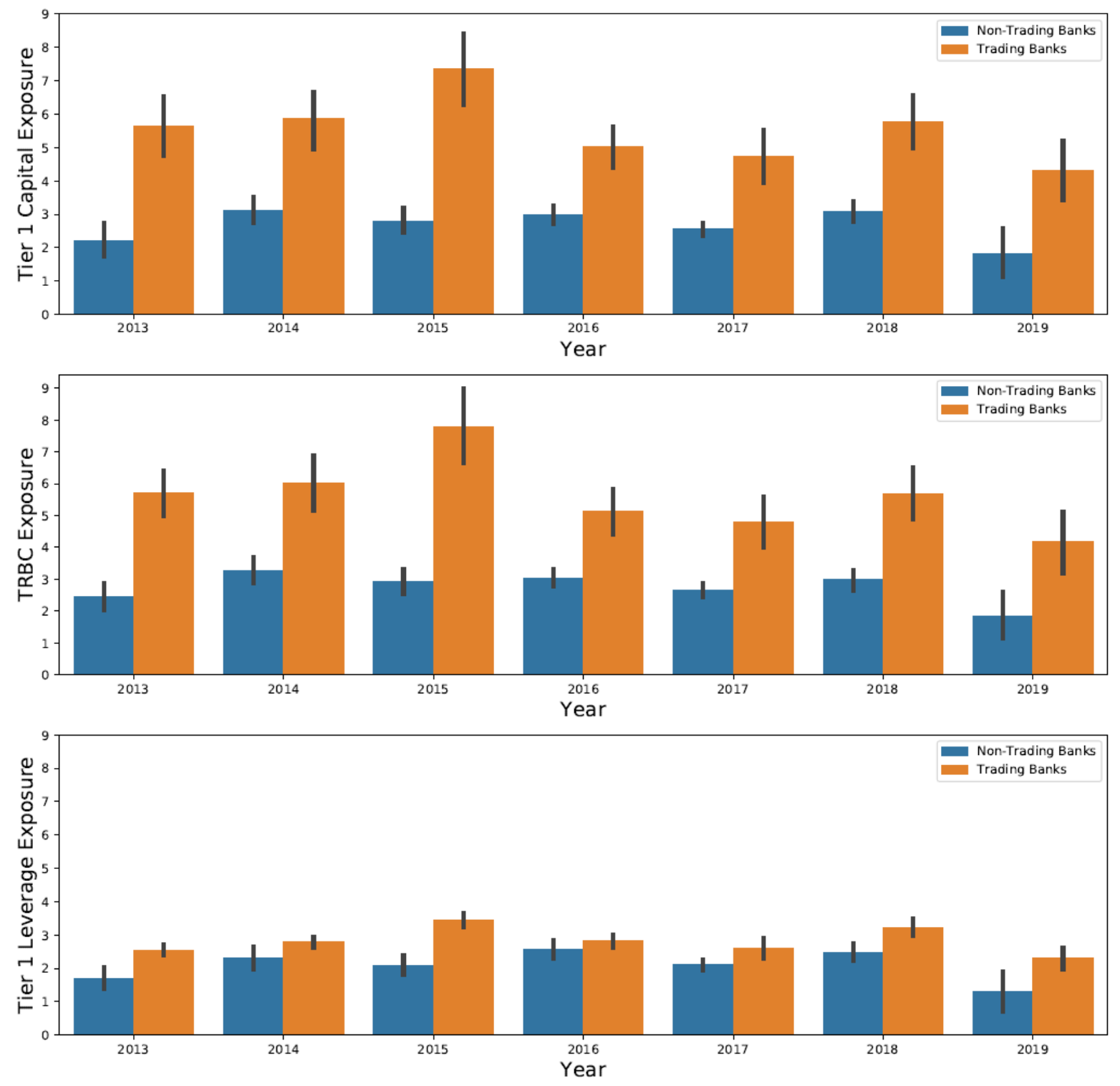
Figure 3: Evolution of Unstressed Bank Capital Ratios \& Distributions
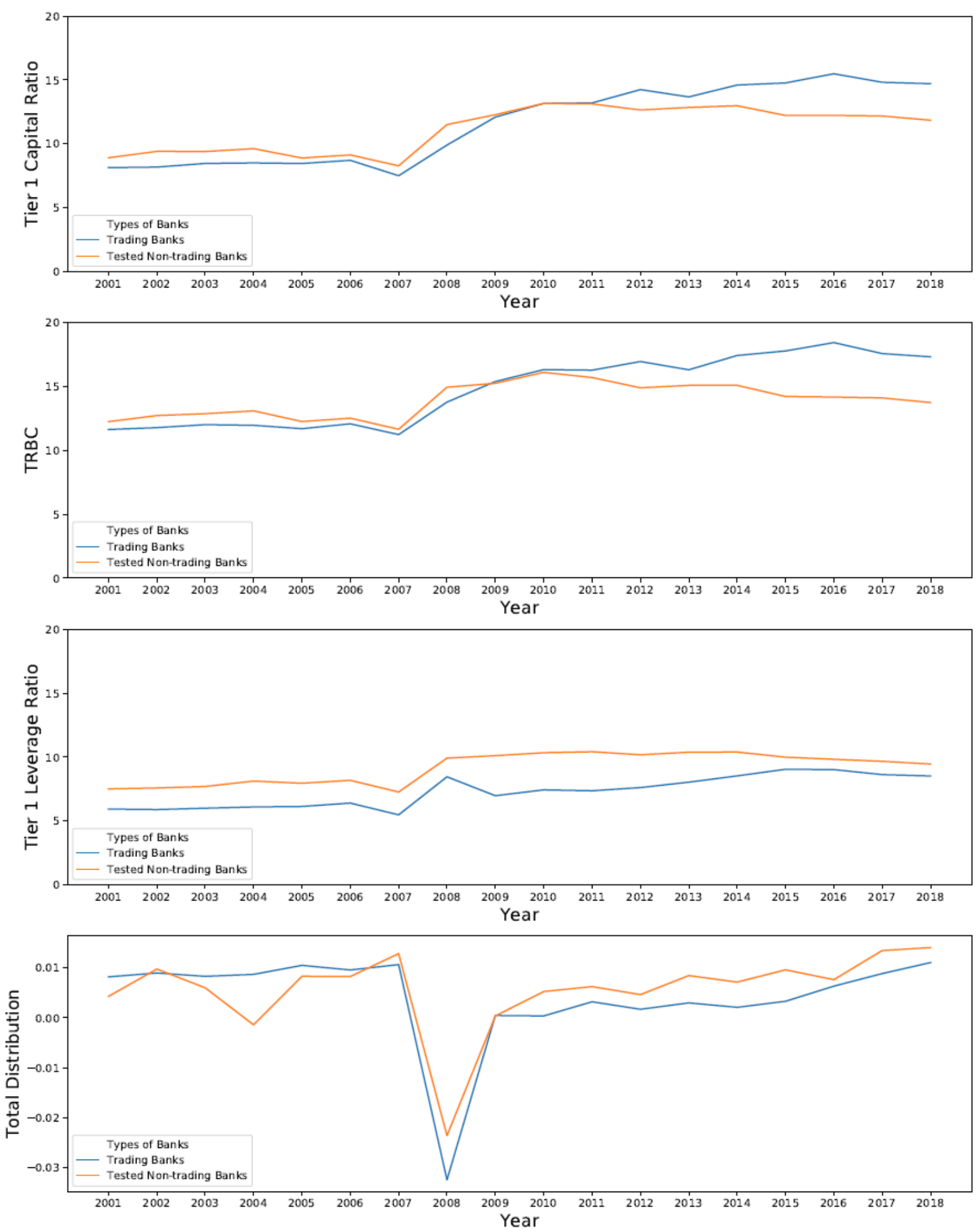
Table 1: Summary Statistics

Sample includes all stress-tested U.S. banks from 2013 through 2019.

\begin{tabular}{|c|c|c|c|c|c|c|c|c|c|}
\hline \multicolumn{10}{|c|}{ Panel A: Summary Statistics for Stress Test Outcomes } \\
\hline & & & Mean & Std.De & & p10 & $\mathrm{p}$ & & p90 \\
\hline \multicolumn{10}{|c|}{ DFAST Outcomes - Fed } \\
\hline \multicolumn{3}{|c|}{ Stressed T1 Capital } & 9.54 & 1.89 & & 7.40 & 9. & 30 & 12.30 \\
\hline \multicolumn{3}{|l|}{ Stressed TRBC } & 11.76 & 1.78 & & 9.60 & 11. & 60 & 14.30 \\
\hline \multicolumn{3}{|l|}{ Stressed T1 Leverage } & 7.04 & 1.65 & & 4.90 & 7. & 0 & 8.80 \\
\hline \multicolumn{3}{|l|}{ Minimum Distance } & 3.05 & 1.56 & & 1.01 & 2. & 00 & 5.18 \\
\hline \multicolumn{3}{|l|}{ T1 Capital Exposure } & 3.53 & 2.13 & & 1.10 & 3. & 10 & 6.40 \\
\hline \multicolumn{3}{|l|}{ TRBC Exposure } & 3.61 & 2.15 & & 1.20 & 3. & 20 & 6.50 \\
\hline \multicolumn{3}{|l|}{ T1 Leverage Exposure } & 2.36 & 1.12 & & 0.80 & 2. & & 3.70 \\
\hline \multicolumn{10}{|c|}{ DFAST Outcomes - Bank } \\
\hline \multicolumn{3}{|c|}{ Stressed T1 Capital } & 10.26 & 1.54 & & 8.40 & 10 . & 00 & 12.20 \\
\hline \multicolumn{3}{|l|}{ Stressed TRBC } & 12.57 & 1.53 & & 10.90 & 12 . & 50 & 14.60 \\
\hline \multicolumn{3}{|l|}{ Stressed T1 Leverage } & 7.70 & 1.69 & & 5.50 & 7.8 & 35 & 9.70 \\
\hline \multicolumn{3}{|l|}{ Minimum Distance } & 3.89 & 1.41 & & 2.20 & 3. & 75 & 5.80 \\
\hline \multicolumn{3}{|l|}{ T1 Capital Exposure } & 2.81 & 1.85 & & 0.90 & 2. & 30 & 5.10 \\
\hline \multicolumn{3}{|l|}{ TRBC Exposure } & 2.79 & 1.90 & & 0.90 & 2. & 25 & 5.30 \\
\hline \multicolumn{3}{|l|}{ T1 Leverage Exposure } & 1.70 & 0.90 & & 0.60 & 1. & 0 & 2.90 \\
\hline \multicolumn{10}{|c|}{ CCAR Outcomes - Fed } \\
\hline \multicolumn{3}{|l|}{ Stressed T1 Capital } & 8.06 & 1.63 & & 6.30 & 7. & 70 & 10.30 \\
\hline \multicolumn{3}{|l|}{ Stressed TRBC } & 10.38 & 1.61 & & 8.40 & 10. & & 12.40 \\
\hline \multicolumn{3}{|l|}{ Stressed T1 Leverage } & 5.90 & 1.26 & & 4.20 & 5.9 & 90 & 7.80 \\
\hline \multicolumn{3}{|l|}{ Minimum Distance } & 1.58 & 1.32 & & -0.20 & 1.5 & 50 & 3.22 \\
\hline \multicolumn{3}{|l|}{ Any Failure } & 0.18 & 0.38 & & 0.00 & $0 .($ & 00 & 1.00 \\
\hline \multicolumn{3}{|l|}{ Failure Score } & 0.21 & 0.48 & & 0.00 & 0.0 & 00 & 1.00 \\
\hline Pant & l B: $\mathrm{Cc}$ & rrelati & on Matrix & for Stre & essed & Capital & Ratios & & \\
\hline & Stres: & ed T1 & Capital & $\underline{\text { Stres }}$ & sed $\mathrm{T}$ & $\mathrm{RBC}$ & Stress & sed T1 & everage \\
\hline & $\mathrm{v1}$ & $\mathrm{v} 2$ & v3 & v1 & $\mathrm{v} 2$ & v3 & v1 & $\mathrm{v} 2$ & v3 \\
\hline v1 DFAST-Fed & 1.00 & & & 1.00 & & & 1.00 & & \\
\hline v2 DFAST-Bank & 0.76 & 1.00 & & 0.72 & 1.00 & & 0.86 & 1.00 & \\
\hline v3 CCAR-Fed & 0.76 & 0.48 & 1.00 & 0.73 & 0.41 & 1.00 & 0.75 & 0.62 & 1.00 \\
\hline Panel C: S & mary & tati & s for & ital Pl & ans ar & nd Infl & ce 1 & asures & \\
\hline Capital Plan Meas & res & & & & & & & & \\
\hline Capital Plan & & & 1.19 & 1.12 & & 0.11 & 0. & 95 & 2.22 \\
\hline Total Distributions & & & 0.87 & 0.78 & & 0.17 & 0.7 & 74 & 2.06 \\
\hline Percent Repurchase & & & 51.32 & 25.13 & & 0.00 & 58. & 70 & 78.05 \\
\hline Influence Measures & & & & & & & & & \\
\hline Regulatory Connectior & & & 0.31 & 0.46 & & 0.00 & 0.0 & & 1.00 \\
\hline Trading Bank & & & 0.27 & 0.45 & & 0.00 & 0.0 & & 1.00 \\
\hline Political Donations an & Lobby & ing & 0.00 & 1.00 & & -1.08 & -0 & & 1.55 \\
\hline
\end{tabular}

Note: All continuous variables are winsorized at the 1st and 99th levels 
Table 2: Exposure to Stress Tests

This table shows that capital ratios decline more under the DFAST-Fed stress test model for Trading Banks. In Columns 1,2 , and 3, the dependent variable equals the difference between banks' minimum stressed capital ratios from their initial values, and Column 4 studies banks' minimum distance to regulatory capital requirement thresholds. All variables are defined in Appendix 1. Estimation based on OLS with year fixed effects and heteroskedasticity-robust standard errors clustered at the bank-level (in parenthesis).

\section{Stress Test Outcomes from DFAST-Fed Model}
(1)
$(2)$
$(3)$

(4)

T1 Cap. Exposure TRBC Exposure T1 Lev. Exposure Min Distance

\begin{tabular}{lcccc}
\hline Regulatory Connection & -0.38 & -0.35 & -0.32 & -0.23 \\
& $(0.41)$ & $(0.43)$ & $(0.26)$ & $(0.36)$ \\
Trading Bank & $2.95^{* * *}$ & $2.95^{* * *}$ & $0.76^{* * *}$ & $-0.92^{* *}$ \\
& $(0.85)$ & $(0.83)$ & $(0.27)$ & $(0.39)$ \\
Political Donations and Lobbying & 0.15 & 0.17 & 0.03 & -0.10 \\
& $(0.22)$ & $(0.24)$ & $(0.13)$ & $(0.19)$ \\
Year FEs & Yes & Yes & Yes & Yes \\
\hline Observations & 154 & 154 & 154 & 154 \\
Adjusted $R^{2}$ & 0.35 & 0.35 & 0.10 & 0.07 \\
\hline
\end{tabular}

${ }^{*} p<0.1,{ }^{* *} p<0.05,{ }^{* * *} p<0.01$ 
Table 3: Exposure to Stress Tests, Controlling for Bank-Model Outcomes

This table shows that capital ratios decline more under the DFAST-Fed stress test model for Trading Banks. In Columns 1,2 , and 3, the dependent variable equals the difference between banks' minimum stressed capital ratios from their initial values, and Column 4 studies banks' minimum distance to regulatory capital requirement thresholds. All variables are defined in Appendix 1. Estimation based on OLS with year fixed effects and heteroskedasticity-robust standard errors clustered at the bank-level (in parenthesis).

\begin{tabular}{|c|c|c|c|c|}
\hline & $\begin{array}{l}\text { (1) } \\
\text { Ttress } \\
\text { T1 Cap. Exposure }\end{array}$ & $\begin{array}{l}\text { Test Outcomes fr } \\
\text { (2) } \\
\text { TRBC Exposure }\end{array}$ & $\begin{array}{l}\text { DFAST-Fed Mode } \\
\text { (3) } \\
\text { T1 Lev. Exposure }\end{array}$ & $\begin{array}{c}(4) \\
\text { Min Distance }\end{array}$ \\
\hline Regulatory Connection & $\begin{array}{c}-0.04 \\
(0.33)\end{array}$ & $\begin{array}{l}-0.10 \\
(0.33)\end{array}$ & $\begin{array}{l}-0.04 \\
(0.25)\end{array}$ & $\begin{array}{l}-0.18 \\
(0.31)\end{array}$ \\
\hline Trading Bank & $\begin{array}{c}0.98^{* *} \\
(0.45)\end{array}$ & $\begin{array}{l}1.11^{* *} \\
(0.46)\end{array}$ & $\begin{array}{c}0.44^{*} \\
(0.22)\end{array}$ & $\begin{array}{c}-0.77^{*} \\
(0.39)\end{array}$ \\
\hline Political Donations and Lobbying & $\begin{array}{c}0.19 \\
(0.16)\end{array}$ & $\begin{array}{c}0.19 \\
(0.17)\end{array}$ & $\begin{array}{c}0.05 \\
(0.12)\end{array}$ & $\begin{array}{l}-0.17 \\
(0.15)\end{array}$ \\
\hline T1 Cap. Exposure, DFAST-Bank & $\begin{array}{c}0.80^{* * *} \\
(0.12)\end{array}$ & & & \\
\hline TRBC Exposure, DFAST-Bank & & $\begin{array}{c}0.75^{* * *} \\
(0.12)\end{array}$ & & \\
\hline T1 Lev. Exposure, DFAST-Bank & & & $\begin{array}{c}0.72^{* * *} \\
(0.14)\end{array}$ & \\
\hline Min Distance, DFAST-Bank & & & & $\begin{array}{c}0.66^{* * *} \\
(0.12)\end{array}$ \\
\hline Year FEs & Yes & Yes & Yes & Yes \\
\hline Observations & 154 & 154 & 154 & 154 \\
\hline Adjusted $R^{2}$ & 0.67 & 0.66 & 0.41 & 0.42 \\
\hline
\end{tabular}

${ }^{*} p<0.1,{ }^{* *} p<0.05,{ }^{* * *} p<0.01$ 
Table 4: CCAR Failure

This table shows that Trading Banks are more likely to fail CCAR than other banks. Columns 1 and 2 model CCAR failure as a binary outcome (linear probability model), and Columns 3 and 4 employ a categorical measure that accounts for the intensity of failure (see Appendix 4). All variables are defined in Appendix 1. Estimation based on OLS with year fixed effects and heteroskedasticity-robust standard errors clustered at the bank-level (in parenthesis).

\begin{tabular}{|c|c|c|c|c|}
\hline & \multicolumn{2}{|c|}{ Any Failure } & \multicolumn{2}{|c|}{ Failure Score } \\
\hline & $(1)$ & $(2)$ & $(3)$ & $(4)$ \\
\hline Regulatory Connection & $\begin{array}{l}-0.04 \\
(0.07)\end{array}$ & $\begin{array}{l}-0.04 \\
(0.07)\end{array}$ & $\begin{array}{l}-0.09 \\
(0.08)\end{array}$ & $\begin{array}{l}-0.09 \\
(0.07)\end{array}$ \\
\hline Trading Bank & $\begin{array}{l}0.22^{* *} \\
(0.09)\end{array}$ & $\begin{array}{c}0.17^{* *} \\
(0.08)\end{array}$ & $\begin{array}{l}0.21^{* *} \\
(0.09)\end{array}$ & $\begin{array}{l}0.16^{*} \\
(0.08)\end{array}$ \\
\hline Political Donations and Lobbying & $\begin{array}{c}0.02 \\
(0.04)\end{array}$ & $\begin{array}{c}0.01 \\
(0.04)\end{array}$ & $\begin{array}{l}-0.00 \\
(0.05)\end{array}$ & $\begin{array}{l}-0.02 \\
(0.05)\end{array}$ \\
\hline Below Any Barrier, DFAST-Bank & $\begin{array}{c}\text { Not } \\
\text { Identified }\end{array}$ & & $\begin{array}{c}\text { Not } \\
\text { Identified }\end{array}$ & \\
\hline Min Distance, DFAST-Bank & $\begin{array}{l}-0.00 \\
(0.03)\end{array}$ & & $\begin{array}{c}0.01 \\
(0.03)\end{array}$ & \\
\hline Below Any Barrier, DFAST-Fed & & $\begin{array}{c}0.58^{* * *} \\
(0.16)\end{array}$ & & $\begin{array}{l}1.04^{* *} \\
(0.50)\end{array}$ \\
\hline Min Distance, DFAST-Fed & & $\begin{array}{l}-0.05^{*} \\
(0.02)\end{array}$ & & $\begin{array}{l}-0.03 \\
(0.03)\end{array}$ \\
\hline Year FEs & Yes & Yes & Yes & Yes \\
\hline Observations & 154 & 154 & 154 & 154 \\
\hline Adjusted $R^{2}$ & 0.06 & 0.13 & 0.04 & 0.12 \\
\hline
\end{tabular}

${ }^{*} p<0.1,{ }^{* *} p<0.05,{ }^{* * *} p<0.01$ 
Table 5: Bank Capital Plan

This table shows that Trading Banks plan less aggressive capital actions relative to other banks. The dependent variable equals a proxy for each bank's plan under CCAR, as described in Appendix 2. All variables are defined in Appendix 1. Estimation based on OLS with year fixed effects and heteroskedasticity-robust standard errors clustered at the bank-level (in parenthesis).

\begin{tabular}{lcccc}
\hline & \multicolumn{4}{c}{ Capital Plan } \\
& $(1)$ & $(2)$ & $(3)$ & $(4)$ \\
\hline Regulatory Connection & 0.06 & 0.09 & 0.11 & 0.07 \\
& $(0.17)$ & $(0.20)$ & $(0.13)$ & $(0.17)$ \\
Trading Bank & $-0.55^{*}$ & -0.40 & & \\
& $(0.29)$ & $(0.29)$ & & \\
Political Donations and Lobbying & 0.27 & 0.25 & 0.04 & 0.07 \\
& $(0.18)$ & $(0.15)$ & $(0.20)$ & $(0.18)$ \\
Pct Repurchases & $0.02^{* *}$ & $0.01^{*}$ & $0.02^{* * *}$ & $0.01^{*}$ \\
& $(0.01)$ & $(0.01)$ & $(0.01)$ & $(0.01)$ \\
Min Distance, DFAST-Bank & & $0.38^{* * *}$ & & $0.22^{* *}$ \\
& & $(0.10)$ & & $(0.09)$ \\
Year FEs & Yes & Yes & Yes & Yes \\
Bank FEs & No & No & Yes & Yes \\
\hline Observations & 154 & 154 & 154 & 154 \\
Adjusted $R^{2}$ & 0.21 & 0.41 & 0.64 & 0.68 \\
\hline
\end{tabular}

${ }^{*} p<0.1,{ }^{* *} p<0.05,{ }^{* * *} p<0.01$ 
Table 6: Actual Capital Distributions

This table shows that banks' planned capital actions under CCAR are reflected in their actual capital distributions (the dependent variable). The dependent variable measures total distributions made in the four quarters following CCAR. All variables are defined in Appendix 1. Estimation based on OLS with year fixed effects and heteroskedasticity-robust standard errors clustered at the bank-level (in parenthesis).

\begin{tabular}{lcccc}
\hline & $(1)$ & $(2)$ & $(3)$ & $(4)$ \\
\hline Regulatory Connection & 0.03 & 0.00 & 0.04 & 0.00 \\
& $(0.14)$ & $(0.08)$ & $(0.11)$ & $(0.08)$ \\
Trading Bank & $-0.40^{* *}$ & -0.12 & & \\
& $(0.19)$ & $(0.08)$ & & \\
Political Donations and Lobbying & 0.12 & -0.03 & -0.11 & $-0.13^{*}$ \\
& $(0.09)$ & $(0.04)$ & $(0.09)$ & $(0.08)$ \\
Capital Plan & & $0.48^{* * *}$ & & $0.36^{* * *}$ \\
& & $(0.06)$ & & $(0.11)$ \\
Pct Repurchases & $0.01^{* *}$ & 0.00 & $0.01^{*}$ & 0.00 \\
& $(0.01)$ & $(0.00)$ & $(0.00)$ & $(0.00)$ \\
Year FEs & Yes & Yes & Yes & Yes \\
Bank FEs & No & No & Yes & Yes \\
\hline Observations & 142 & 142 & 142 & 142 \\
Adjusted $R^{2}$ & 0.26 & 0.72 & 0.71 & 0.82 \\
\hline
\end{tabular}

${ }^{*} p<0.1,{ }^{* *} p<0.05,{ }^{* * *} p<0.01$ 
Table 7: Model Convergance

This paper tests whether measures of bank connectedness are correlated with the difference between stressed capital ratios from the Fed's model vs. the banks' models. The dependent variable equals the absolute (Panel A) or squared (Panel B) difference between Fed and Bank model outcomes. All variables are defined in Appendix 1. Estimation based on OLS with year fixed effects and heteroskedasticity-robust standard errors clustered at the bank-level (in parenthesis).

\begin{tabular}{|c|c|c|c|c|}
\hline & $\begin{array}{l}\text { Absolute Difference } \\
(1) \\
\text { T1 Capital Exposure }\end{array}$ & $\begin{array}{l}\text { getween DFAST-Fe } \\
\text { (2) } \\
\text { TRBC Exposure }\end{array}$ & $\begin{array}{l}\text { and DFAST-Bank Moc } \\
\text { T1 Leverage Exposure }\end{array}$ & $\begin{array}{l}\text { Outcomes } \\
\text { (4) } \\
\text { Min Distance }\end{array}$ \\
\hline Regulatory Connection & $\begin{array}{l}-0.15 \\
(0.22)\end{array}$ & $\begin{array}{l}-0.21 \\
(0.23)\end{array}$ & $\begin{array}{l}-0.01 \\
(0.20)\end{array}$ & $\begin{array}{c}-0.10 \\
(0.28)\end{array}$ \\
\hline Trading Bank & $\begin{array}{c}0.27 \\
(0.23)\end{array}$ & $\begin{array}{c}0.27 \\
(0.25)\end{array}$ & $\begin{array}{c}0.11 \\
(0.15)\end{array}$ & $\begin{array}{c}0.43 \\
(0.32)\end{array}$ \\
\hline Political Donations and Lobbying & $\begin{array}{c}0.06 \\
(0.11)\end{array}$ & $\begin{array}{c}0.07 \\
(0.12)\end{array}$ & $\begin{array}{c}0.06 \\
(0.09)\end{array}$ & $\begin{array}{c}0.11 \\
(0.12)\end{array}$ \\
\hline Year FEs & Yes & Yes & Yes & Yes \\
\hline \multirow{3}{*}{$\begin{array}{l}\text { Observations } \\
\text { Adjusted } R^{2}\end{array}$} & 154 & 154 & 154 & 154 \\
\hline & -0.00 & 0.00 & -0.03 & 0.02 \\
\hline & $\begin{array}{l}\text { Squared Difference } \\
(1) \\
\text { T1 Capital Exposure }\end{array}$ & $\begin{array}{l}\text { etween DFAST-Fe } \\
(2) \\
\text { TRBC Exposure }\end{array}$ & $\begin{array}{l}\text { and DFAST-Bank Mod } \\
\text { T1 Leverage Exposure } \\
\text { Ty }\end{array}$ & $\begin{array}{l}\text { Outcomes } \\
\text { (4) } \\
\text { Min Distance }\end{array}$ \\
\hline Regulatory Connection & $\begin{array}{l}-0.65 \\
(0.66)\end{array}$ & $\begin{array}{l}-1.01 \\
(0.70)\end{array}$ & $\begin{array}{l}-0.11 \\
(0.50)\end{array}$ & $\begin{array}{l}-0.10 \\
(1.20)\end{array}$ \\
\hline Trading Bank & $\begin{array}{c}0.78 \\
(0.81)\end{array}$ & $\begin{array}{c}0.89 \\
(0.89)\end{array}$ & $\begin{array}{c}0.18 \\
(0.37)\end{array}$ & $\begin{array}{c}1.84 \\
(1.37)\end{array}$ \\
\hline Political Donations and Lobbying & $\begin{array}{c}0.19 \\
(0.40)\end{array}$ & $\begin{array}{c}0.17 \\
(0.44)\end{array}$ & $\begin{array}{c}0.07 \\
(0.22)\end{array}$ & $\begin{array}{c}0.40 \\
(0.47)\end{array}$ \\
\hline Year FEs & Yes & Yes & Yes & Yes \\
\hline Observations & 154 & 154 & 154 & 154 \\
\hline Adjusted $R^{2}$ & 0.00 & 0.01 & -0.02 & 0.03 \\
\hline
\end{tabular}

${ }^{*} p<0.1,{ }^{* *} p<0.05,{ }^{* * *} p<0.01$ 
Table 8: Evolution of Bank Capital Ratios \& Distributions

This table shows that Trading Banks increase their actual (unstressed) capital ratios relative to other banks in the advent of the stress test regime. Sample includes annual data from 2001 to 2018, without the three crisis years (2007-2009). All variables are defined in Appendix 1. Estimation based on OLS with year and bank fixed effects and heteroskedasticity-robust standard errors clustered at the bank-level (in parenthesis).

\begin{tabular}{lcccc}
\hline & \multicolumn{3}{c}{ Capital Ratios } & Payouts \\
& $(1)$ & $(2)$ & $(3)$ & $(4)$ \\
& T1 Capital & TRBC & T1 Leverage & Total Distributions \\
\hline Trading Bank $\times$ Post 2013 & $2.03^{* * *}$ & $2.55^{* * *}$ & $1.18^{* * *}$ & -0.00 \\
& $(0.32)$ & $(0.50)$ & $(0.36)$ & $(0.00)$ \\
Bank FEs & Yes & Yes & Yes & Yes \\
Year FEs & Yes & Yes & Yes & Yes \\
\hline Observations & 341 & 341 & 341 & 339 \\
Adjusted $R^{2}$ & 0.82 & 0.74 & 0.77 & 0.25 \\
\hline
\end{tabular}

${ }^{*} p<0.1,{ }^{* *} p<0.05,{ }^{* * *} p<0.01$ 
Table 9: Evolution of Regulatory Connections and Political Contributions

This table shows that Trading Banks do not increase their regulatory or political connectedness in the advent of the stress test regime. Sample includes annual data from 2001 to 2018. All variables are defined in Appendix 1. Estimation based on OLS with year and bank fixed effects and heteroskedasticity-robust standard errors clustered at the bank-level (in parenthesis).

\begin{tabular}{lcc}
\hline & Regulatory Connection & Political Donations and Lobbying \\
& $(1)$ & $(2)$ \\
\hline Trading Bank $\times$ Post 2013 & -0.15 & $-0.37^{*}$ \\
& $(0.19)$ & $(0.20)$ \\
Year FEs & Yes & Yes \\
Bank FEs & Yes & Yes \\
\hline Observations & 399 & 399 \\
Adjusted $R^{2}$ & 0.37 & 0.76 \\
\hline
\end{tabular}

${ }^{*} p<0.1,{ }^{* *} p<0.05,{ }^{* * *} p<0.01$ 